\title{
EXPLORING THE RELATIONSHIP BETWEEN SHORT-TERM BORROWINGS AND PROFITABILITY IN CHINA: THE MODERATING ROLE OF CASH CONVERSION CYCLE
}

\author{
Faisal MAHMOOD ${ }^{*}$, Han DONGPING ${ }^{1}$, Zahoor AHMED ${ }^{2}$, Umeair SHAHZAD ${ }^{3}$, \\ Nazakat $\mathrm{ALI}^{4}$, Wang BODIAN ${ }^{1}$, Muhammad SHAHBAZ ${ }^{5}$ \\ ${ }^{1}$ School of Economy and Management, Harbin Institute of Technology, Harbin, China \\ ${ }^{2}$ School of Management and Economics, Beijing Institute of Technology, Beijing, China \\ ${ }^{3}$ School of Management, Ocean University, Qingdao, China \\ ${ }^{4}$ School of Management, Iqra University, Islamabad, Pakistan \\ ${ }^{5}$ Lyallpur Business School, Government College University, Faisalabad, Pakistan
}

Received 22 December 2019; accepted 02 September 2020

\begin{abstract}
This study focuses on the moderating role of the cash conversion cycle (CCC) and its components while investigating the relationship between short-term borrowings and profitability in Chinese firms. The generalized method of moments (GMM) approach is employed on the panel data over the period 2000 to 2017. The findings reveal a significant moderating role of CCC and its components in the short-term borrowings and profitability relationship. Specifically, the firms following a conservative strategy in CCC and its components, adopt the same strategy in the external financing which lies in the long-term borrowings. Consequently, such firms require less short-term borrowings compared to the full sample. However, the firms following an aggressive strategy in the CCC and its components, do not follow the aggressive strategy in external financing that lies in the short-term borrowings. Instead, these firms adopt the conservative strategy for profit maximization and require less amount of short-term borrowings compared to the full sample. Finally, several policy options are proposed to achieve the optimum relation between short-term borrowings and profitability.
\end{abstract}

Keywords: short-term borrowings, break-even point, profitability, cash conversion cycle, account payable days, account receivable days, inventory days, generalized method of moments.

JEL Classification: G00, D25, G32.

\section{Introduction}

Smith presented a theory in 1980 that working capital management influences profitability, liquidity, and firm value. Based on this theory, literature got extensive growth and not only studied the determinants of working capital management (Baños-Caballero et al., 2010;

${ }^{\star}$ Corresponding author. E-mail: faisal_mahmood217@hit.edu.cn

Copyright (c) 2021 The Author(s). Published by Vilnius Gediminas Technical University

This is an Open Access article distributed under the terms of the Creative Commons Attribution License (http://creativecommons. org/licenses/by/4.0/), which permits unrestricted use, distribution, and reproduction in any medium, provided the original author and source are credited. 
Tsuruta, 2019) but also explored the effect of investment in working capital on firm performance (Altaf \& Ahmad, 2019; Baños-Caballero et al., 2010, 2013; Kieschnick et al., 2013).

However, according to Modigliani and Miller's (1958) theory of capital structure, the mode of financing in working capital is equally essential for firm performance and value. There are two key external sources to finance working capital, namely short- and long-term borrowings (Mahmood et al., 2019; Panda \& Nanda, 2018; Shahzad et al., 2020). Long-term borrowing is free from; interest rate fluctuations (Baños-Caballero et al., 2016), inflation (Panda \& Nanda, 2018), economy changes (Baños-Caballero et al., 2016), and refinancing uncertainties. While short term borrowing carries; low-interest charges, fewer agency problems among stakeholders, and better financing terms and conditions (Panda \& Nanda, 2018). Therefore, firms use a combination of short- and long-term borrowings to finance working capital. The best combination of short- and long-term borrowings ultimately maximizes the profit.

Several studies investigated the short-term borrowings and their impact on profit. Working capital finance (WCF) is a term frequently used for short-term borrowings and refers to the proportion of short-term borrowings in total external financing. Baños-Caballero (2016) studied WCF-Profit relation in the moderating role of financial flexibility. Later on, Panda and Nanda (2018) introduced a new moderating factor named profit-margin, for the WCFProfit relationship in the Indian context. Afterward, Mahmood et al. (2019) contributed to existing literature and provided empirical evidence that firm-size and leverage also influence the WCF-Profit relationship. The current study extends the literature by introducing a new moderating factor, CCC, in the short-term borrowings and profit relationship.

CCC is the period that starts when cash is invested in purchasing the raw material and ends on receiving the money against credit sales (Gill et al., 2019). CCC measures the efficiency of working capital and consists of three elements i-e account payable days, account receivable days, and inventory days. The duration of CCC relies on the working capital management (WCM) strategy of a firm. The aggressive strategy involves short CCC with less inventory holding days, fewer account receivables days, and increased account payable days (Masri \& Abdulla, 2018). In contrast, conservative WCM strategy involves long CCC with extensive inventory holding days, increased account receivable days, and less account payable days (Masri \& Abdulla, 2018). The current study aims to find out the best combination of short- and long-term borrowings for the firms following aggressive or conservative WCM strategies.

Several studies argued the CCC as a tool to measure the working capital efficiency and claimed that its calculation is mathematically incorrect due to different denominators involved (Altaf, 2018). Also, it gives equal weight to its elements, and thus fails to incorporate their unequal values (Afrifa et al., 2016). To counter this criticism, the current study segregated CCC into its three components and evaluated the moderating role of each element in the short-term borrowings and profit relationship.

The current study extends the literature in multiple ways. Firstly, this study evaluated short-term borrowing and profit relationship among Chinese firms of nine manufacturing sectors from 2000 to 2017. China is the second-largest economy and, contrary to other leading economies, exhibits a banking system which is highly centralized and under the influence 
of Government (Laghari \& Chengang, 2019). So, it seems interesting to evaluate how the working capital management and capital structure theories prevail in such a unique banking system. Secondly, this study introduced the moderating role of CCC in short-term borrowings and profitability relationship, which, as per our knowledge, has not been tested yet. Thirdly, the three components of CCC are segregated and separately examined the moderating influence of each element in the short-term borrowings and profit relationship. Besides, the current study also employed the two-step system GMM, an advanced technique among all panel data methodologies, which addresses multicollinearity, heteroskedasticity, and endogeneity with greater strength (Baum et al., 2003).

The rest of the paper contains different sections as follows. Section 1 explains the shortterm borrowings and profitability relationship under the influence of CCC and its components. Section 2 presents the models of the study, explains the variables involved, and elaborates on the econometric methodology. Section 3 analyzes the data and discusses the corresponding results. Last Section concludes the current research and proposes policy recommendations.

\section{Short-term borrowings, profitability, CCC and its components}

Firms use both short- and long-term borrowings to finance the working capital. Short-term financing bears lower interest charges and more readily available, whereas long-term financing earns more time to repay, avoids interest rate fluctuations (Mahmood et al., 2018), and frees from renewal uncertainties (Mahmood et al., 2019). So, a combination of short- and long-term borrowings that maximizes the profit is preferred in working capital financing.

Working capital finance (WCF) refers to the portion of short-term borrowings in total external financing (Baños-Caballero et al., 2016). Baños-Caballero et al. (2016) observed an inverted U-shaped relation in working capital finance and profit. Later on, Panda and Nanda (2018) reported an inverted relation between WCF and profit in most of the manufacturing sectors of India, under the moderating role of financial flexibility and markup. Afterward, Mahmood et al. (2019) found an inverted U-shaped relation in small, large, low leverage, and high leverage companies of China. Considering the above studies, it is expected to have an inverted U-shaped relation in short-term borrowings and profit. So, we design the 1st hypothesis as follows;

H1: There exists an inverted U-shaped relationship between short-term borrowings and Profitability.

The cash conversion cycle is the period that starts from the payment to the suppliers and ends on the collection from account receivables (Baños-Caballero et al., 2019). Firms follow aggressive or conservative strategies in CCC depending upon the personnel expertise (Eldomiaty et al., 2018), the advancement of technology (Tahir \& Anuar, 2016), the strength of relationship with suppliers (Dalci \& Ozyapici, 2018), brand worth (Baños-Caballero et al., 2010), long-term contracts with customers (Gao \& Wang, 2017), and availability of financial resources (Baños-Caballero et al., 2012). The conservative strategy aims to boost-up the sales by extending the CCC via more investment in account receivables and inventory (Moussa, 2018). 
H2a: Firms with extended CCC, exhibit an inverted U-shapedWCF-Profitability relationship with a large proportion of short-term borrowings compared to the full sample.

H2b: Firms with reduced CCC, exhibit an inverted U-shaped WCF-Profitability relationship with a lower proportion of short-term borrowings compared to the full sample.

However, CCC as a tool to measure of working capital efficiency has been criticized in numerous studies. These studies explain that the calculation of CCC is mathematically incorrect as it is the sum of three ratios that do not have the same denominators (Altaf, 2018). Some studies also objected that CCC gives equal weight to receivables, payables, and inventory ignoring their unequal values (Afrifa et al., 2016).

H3a: Firms that offer more time to customers for payments, exhibit an inverted $U$-shaped WCF-Profitability relationship with a large proportion of short-term borrowings compared to the full sample.

H3b: Firms that offer less time to customers for payments, exhibit an inverted $U$-shaped WCF-Profitability relationship with a small proportion of short-term borrowings compared to the full sample.

Conversely, large account payable days cause shorter CCC, while small account payable days result in longer CCC. So, the next hypotheses are formulated as follows;

H4a: Firms that make early payments to suppliers, exhibit an inverted U-shaped WCFProfitability relationship with a small proportion of short-term borrowings compared to the full sample.

H4b: Firms that make late payments to suppliers, exhibit an inverted U-shaped WCFProfitability relationship with a large proportion of short-term borrowings compared to the full sample.

However, Inventory days have the same influence on CCC as account receivable days. Accordingly, the next hypothesis can be formulated as follows;

H5a: Firms that maintain a high level of inventory, exhibit an inverted U-shaped WCFProfitability relationship with a large proportion of short-term borrowings compared to the full sample.

H5b: Firms that maintain a low level of inventory, exhibit an inverted U-shaped WCFProfitability relationship with a small proportion of short-term borrowings compared to the full sample.

\section{Variables and research models}

The current study uses ROE (return on equity) as a dependent variable, which is a proxy for profitability. Short-term borrowings (Sborrowings) is an independent variable. Furthermore, a non-linear term of short-term borrowings is used to discover the break-even point. Thus, the Model (1) is constructed to estimate the short-term borrowings and profitability relationship. To avoid the influence of other factors, size, growth, and leverage are used as control variables.

$$
\begin{aligned}
& R O E_{i t}=\alpha+\beta_{1} \text { Sborrowings }_{i t}+\beta_{2} \text { Sborrowings }_{i t}^{2}+\beta_{3} \text { Size }_{i t}+ \\
& \beta_{4} \text { Growth }_{i t}+\beta_{5} \text { Leverage }_{i t}+\lambda_{t}+\eta_{i}+\varepsilon_{i t} .
\end{aligned}
$$


Here, the net profit is divided by equity to calculate the value of $R O E$. Sborrowings is calculated by dividing short-term borrowings over total loans. Size of the firm is measured by taking a log of total assets, The growth rate of sales calculates growth, and leverage is the value of total debts divided by total assets. $\lambda_{t}$ is the dummy variable for the time that changes over time but remains constant within the year. $\eta_{i}$ is the specific characteristics of a firm that do not change over time and make it different from other firms. Finally, $\varepsilon_{i t}$ is the undefined error term of the model.

Following Baños-Caballero et al. (2016), the current study calculated the break-even point of the non-linear relation in short-term borrowings and profit by $-\beta_{1} / 2 \beta_{2}$. The result of this formula shows the proportion of short-term borrowings in total external financing that should be maintained to get the maximum profit.

\subsection{Cash Conversion Cycle (CCC)}

First, the effect of CCC in the short-term borrowings and profit relationship is estimated. Following (Baños-Caballero et al., 2010; Chauhan \& Banerjee, 2018; Goel \& Sharma, 2015; Lyngstadaas \& Berg, 2016) we computed CCC using the following formula:

$\mathrm{CCC}=$ Account Receivable Days - Account Payable days + Inventory Days, where:

Account Receivable Days = Account Receivables / Sales;

Account Payable Days = Account Payables / Purchases;

Inventory Days = Inventory / Cost of Goods Sold.

To incorporate the moderating effects of CCC, the current study introduced a dummy variable called CCC dummy, which has values of $1(0)$ for firms having a CCC period larger (smaller) than the median of the sample.

We, therefore, amended the first model to assess the moderating effects of CCC in the nonlinear relationship between short-term borrowings and profitability:

$$
\begin{aligned}
& R_{i t}=\alpha+\beta_{1} \text { Sborrowings }_{i t}+\beta_{2} \text { Sborrowings }_{i t}^{2}+\gamma_{1} \text { Sborrowings }_{i t} \times \\
& \text { CCC }_{i t} \text { Dummy }+\gamma_{2} \text { Sborrowings }_{i t}^{2} \times C C C_{i t} \text { Dummy }+\beta_{3} \text { Size }_{i t}+ \\
& \beta_{4} \text { Growth }_{i t}+\beta_{5} \text { Leverage }_{i t}+\lambda_{t}+\eta_{i}+\varepsilon_{i t} .
\end{aligned}
$$

Under the influence of $C C C$, this model presents a different break-even point calculated as $-\left(\beta_{1}+\gamma_{1}\right) / 2\left(\beta_{2}+\gamma_{2}\right)$.

We amended the model (1) to capture the moderating role of account receivable days in the short-term borrowings and profit relationship:

$$
\begin{aligned}
& R_{i t}=\alpha+\beta_{1} \text { Sborrowings }_{i t}+\beta_{2} \text { Sborrowings }_{i t}^{2}+\Phi_{1} \text { Sborrowings }_{i t} \times \\
& A / R \text { Days }_{i t} \text { Dummy } \Phi_{2} \text { Sborrowings }_{i t}^{2} \times A / R \text { Days }_{i t} \text { Dummy }+\beta_{3} \text { Size }_{i t}+ \\
& \beta_{4} \text { Growth }_{i t}+\beta_{5} \text { Leverage }_{i t}+\lambda_{t}+\eta_{i}+\varepsilon_{i t} .
\end{aligned}
$$


Under the influence of account receivable days, this model presents a different break-even point calculated as $-\left(\beta_{1}+\Phi_{1}\right) / 2\left(\beta_{2}+\Phi_{2}\right)$.

We amended the model (1) to capture the moderating role of account payable days in the short-term borrowings and profit relationship:

$$
\begin{aligned}
& R_{i t}=\alpha+\beta_{1} \text { Sborrowings }_{i t}+\beta_{2} \text { Sborrowings }_{i t}^{2}+v_{1} \text { Sborrowings }_{i t} \times \\
& \text { A / P Days } \text { Dummy }_{i t} \text { D }_{2} \text { Sborrowings }_{i t}^{2} \times A / P \text { Days }_{i t} \text { Dummy }+\beta_{3} \text { Size }_{i t}+ \\
& \beta_{4} \text { Growth }_{i t}+\beta_{5} \text { Leverage }_{i t}+\lambda_{t}+\eta_{i}+\varepsilon_{i t} .
\end{aligned}
$$

Under the influence of account receivable days, this model presents a different break-even point calculated as $-\left(\beta_{1}+v_{1}\right) / 2\left(\beta_{2}+v_{2}\right)$.

We amended the model (1) to capture the moderating influence of Inventory days in the short-term borrowings and profit relationship:

$$
\begin{aligned}
& \text { ROE }_{i t}=\alpha+\beta_{1} \text { Sborrowings }_{i t}+\beta_{2} \text { Sborrowings }_{i t}^{2}+\Psi_{1} \text { Sborrowings }_{i t} \times \\
& \text { Inv Days }_{i t} \text { Dummy } \Psi_{2} \text { Sborrowings }_{i t}^{2} \times \text { Inv Days }_{i t} \text { Dummy } \beta_{3} \text { Size }_{i t}+ \\
& \beta_{4} \text { Growth }_{i t}+\beta_{5} \text { Leverage }_{i t}+\lambda_{t}+\eta_{i}+\varepsilon_{i t} .
\end{aligned}
$$

Under the influence of inventory days, this model presents a different break-even point calculated by $-\left(\beta_{1}+\Psi_{1}\right) / 2\left(\beta_{2}+\Psi_{2}\right)$.

The current study uses panel data and applies the GMM estimation technique.GMM, among all the panel data analytical techniques, is the best to deal with endogeneity (Li, 2016). GMM has several techniques to create these instrumental variables. This study used two-step system GMM, an advanced GMM estimation proposed by Blundell and Bond (Blundell \& Bond, 1998), which creates valid instrumental variables and ultimately produces reliable results, even in the presence of heteroskedasticity. As the reliability of GMM depends on the reliability of the instruments, therefore, the Hansen test is applied to evaluate the reliability of instrumental variables.

\subsection{Data and sample}

This study uses the data from published accounts of the manufacturing firms listed in the Shanghai stock exchange during the period 2000 to 2017. Data is collected from the CSMAR (China Securities Market and Accounting Research) database. This database is frequently referred for studies in the Chinese context (Mahmood et al., 2019). This study used the refined sample of 12,366 observations.

\section{Analysis and results}

\subsection{Descriptive statistics}

Table 1 carries some essential information about the data, such as mean, median, and standard deviation of the variables involved in the equations. 
Table 1. Descriptive detail

\begin{tabular}{|c|c|c|c|c|c|c|}
\hline Variable & $\mathrm{N}$ & Mean & Median & SD & Min & Max \\
\hline ROE & 12,366 & 0.308 & 0.237 & 0.473 & -2.737 & 3.041 \\
\hline Short-term borrowings & 12,366 & 0.367 & 0.325 & 0.252 & 0.00432 & 1.000 \\
\hline Short-term borrowings ${ }^{2}$ & 12,366 & 0.198 & 0.106 & 0.231 & $1.87 \mathrm{e}-05$ & 0.999 \\
\hline Size & 12,366 & 9.458 & 9.398 & 0.511 & 7.580 & 11.54 \\
\hline Growth & 12,366 & 2.258 & 1.221 & 3.559 & -0.910 & 55.39 \\
\hline Leverage & 12,366 & 0.448 & 0.438 & 0.203 & 0.0188 & 0.994 \\
\hline A/R days & 12,366 & 83.51 & 62.451 & 75.84 & 1 & 363 \\
\hline $\mathrm{A} / \mathrm{P}$ days & 12,366 & 77.37 & 65.358 & 54.84 & 1 & 362 \\
\hline Inventory days & 12,366 & 129.1 & 102.495 & 88.82 & 1 & 364 \\
\hline $\mathrm{CCC}$ & 12,366 & 135.3 & 112.553 & 112.1 & -317 & 365 \\
\hline
\end{tabular}

\subsection{Correlation}

Table 2 presents the correlation between all the variables of the study. ROE and short-term borrowings have a significant correlation. Moreover, mostly control and independent variables show a significant correlation with each other. However, some relations, i-e growth, and short-term borrowings are not significant.

\subsection{Short-term borrowings and return on equity}

Model (1) elaborates on the short-term borrowings and profitability relationship in Chinese firms. Detail results of the Eq. (1) are given in Table 3. Results explain that the coefficient value for each explanatory variable is strongly significant at the 0.00 level. The coefficients of short-term borrowings and its square have positive and negative values that confirm the non-linear and inverted U-shaped relationship between short-term borrowings and profitability. Breakeven point of this relationship, computed as $[-2.72 /(-2.62 \times 2)]$, is 0.52 . This value explains that there must be $52 \%$ short-term and $48 \%$ long-term borrowings in total external financing to achieve the maximum profit.

Hansen test measures the validity of instrumental variables via overidentifying restrictions. If the p-value of the Hansen test is greater than 0.05 then it accepts the null hypothesis that "all overidentifying restrictions are jointly valid" and hence validates the instrumental variables of the model. Similarly, the first-order autocorrelation AR(1) measures the correlation of successive residuals while 2nd order autocorrelation AR (2) measures the autocorrelation of two periods apart residuals of a model.

\section{Short-term borrowings and Profitability under the moderating role of CCC}

Results in Table 4 confirm the existence of an inverted U-shaped relation in short-term borrowings and profit for firms having extended CCC period. This relationship is a combination of positive and negative trends, separated by a break-even point. The break-even point, in this case, is $0.63[-(4.04-1.73) /(2 \times(-4.48+2.65))]$ which explains that external financing must have a combination of $63 \%$ and $37 \%$ for short- and long-term borrowings. 


\begin{tabular}{|c|c|c|c|c|c|c|c|c|c|c|}
\hline ن & & & & & & & & & & - \\
\hline 苞 & & & & & & & & & - & 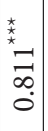 \\
\hline 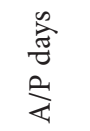 & & & & & & & & - & 竢 & 齐 \\
\hline 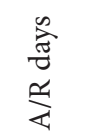 & & & & & & & - & 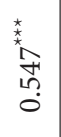 & 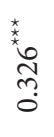 & $\begin{array}{l}\text { 齐 } \\
\stackrel{0}{0} \\
\stackrel{0}{0} \\
0\end{array}$ \\
\hline 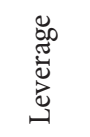 & & & & & & - & 索 & 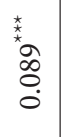 & 棠 & 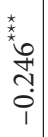 \\
\hline 苞 & & & & & - & $\begin{array}{l}\text { t. } \\
\stackrel{1}{1} \\
0 \\
0 \\
0 \\
1\end{array}$ & $\begin{array}{l}\text { t. } \\
\text { 응 } \\
0 \\
0 \\
0 \\
1\end{array}$ & $\begin{array}{l}\text { t } \\
{ }^{*} \infty \\
\infty \\
0 \\
0 \\
0 \\
1\end{array}$ & 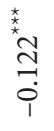 & 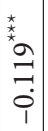 \\
\hline$\stackrel{\tilde{N}}{\sim}$ & & & & - & \begin{tabular}{l} 
t) \\
\multirow{x}{*}{$\infty$} \\
$\stackrel{0}{0}$ \\
0 \\
0
\end{tabular} & 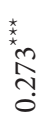 & 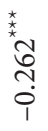 & $\begin{array}{l}\stackrel{m}{0} \\
\stackrel{0}{0} \\
1\end{array}$ & 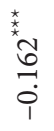 & 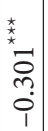 \\
\hline 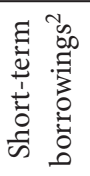 & & & - & 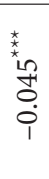 & \begin{tabular}{l} 
t.t. \\
\multirow{x}{*}{0} \\
0 \\
0 \\
0
\end{tabular} & 离 & 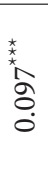 & $\begin{array}{l}\tilde{n} \\
\stackrel{n}{0} \\
\stackrel{0}{0}\end{array}$ & 齐 & 齐 \\
\hline 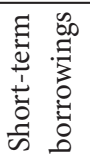 & & - & 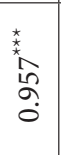 & 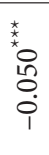 & $\begin{array}{l}\stackrel{+}{\sigma} \\
\stackrel{0}{0}\end{array}$ & 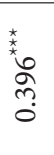 & $\begin{array}{l}\text { 枽 } \\
\text { 合 } \\
0 \\
0\end{array}$ & 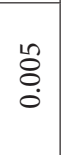 & 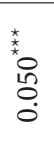 & 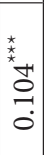 \\
\hline$\stackrel{\text { 떰 }}{2}$ & - & 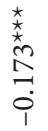 & 索 & 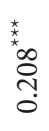 & તู & 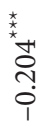 & $\begin{array}{l}\text { 齐 } \\
\text { in } \\
\vdots \\
1\end{array}$ & 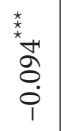 & \begin{tabular}{l} 
t. \\
\multirow{2}{*}{} \\
0 \\
0 \\
0 \\
1
\end{tabular} & 齐 \\
\hline & \begin{tabular}{l} 
II \\
\hdashline \\
$\approx$
\end{tabular} & 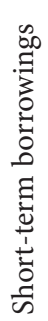 & 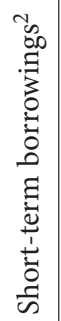 & 今 & 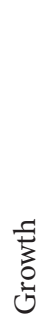 & 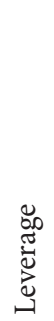 & $\begin{array}{l}\frac{n}{2} \\
\frac{\pi}{2} \\
\frac{1}{2}\end{array}$ & \begin{tabular}{l}
0 \\
\multirow{3}{*}{} \\
2 \\
2
\end{tabular} & $\begin{array}{l}\infty \\
\hat{\overbrace{}} \\
\dot{\Xi} \\
\dot{\Xi}\end{array}$ & ن \\
\hline
\end{tabular}


Table 3. Short-term borrowings and Profitability

\begin{tabular}{|c|c|}
\hline Variables & Equation (1) \\
\hline Short-term borrowings & $\begin{array}{c}2.724^{* * *} \\
(0.962)\end{array}$ \\
\hline Short-term borrowings ${ }^{2}$ & $\begin{array}{c}-2.63^{\star * *} \\
(1.036)\end{array}$ \\
\hline Size & $\begin{array}{c}1.247^{\star * *} \\
(0.101)\end{array}$ \\
\hline Growth & $\begin{array}{c}0.037^{\star * *} \\
(0.005)\end{array}$ \\
\hline Leverage & $\begin{array}{c}-2.634^{\star * *} \\
(0.210)\end{array}$ \\
\hline Constant & $\begin{array}{c}-15.445^{\star * \star} \\
(1.840)\end{array}$ \\
\hline Observations & 12,366 \\
\hline Number of stock-code & 1,648 \\
\hline Breusch-pagan/Cook-Weisberg test & $105.15^{\star * *}$ \\
\hline Hansen Test & 43.78 \\
\hline $\mathrm{AR}(1)$ & -7.55 \\
\hline $\mathrm{AR}(2)$ & -1.60 \\
\hline
\end{tabular}

Note: Return on equity is the dependent variable. Time dummies are incorporated in the model but not reported. Breusch-pagan/Cook-Weisberg test calculates the heteroskedasticity. Hansen test measures the validity of instrumental variables via overidentifying restrictions. Standard errors are in the parentheses. ${ }^{*} \mathrm{p}<0.1, \mathrm{p}^{\star *}<0.05,{ }^{* * *} \mathrm{p}<0.01$.

Table 4. Short-term borrowings and Profitability for firms having reduced and extended CCC period

\begin{tabular}{|c|c|}
\hline Variables & Equation (2) \\
\hline Short-term borrowings & $\begin{array}{c}4.045^{\star * *} \\
(1.198)\end{array}$ \\
\hline Short-term borrowings ${ }^{2}$ & $\begin{array}{c}-4.483^{\star * *} \\
(1.446)\end{array}$ \\
\hline Short-term borrowings ${ }^{\star}$ CCC dummy & $\begin{array}{c}-1.733^{\star * *} \\
(0.649)\end{array}$ \\
\hline Short-term borrowings ${ }^{2 \star} \mathrm{CCC}$ dummy & $\begin{array}{c}2.659^{\star * *} \\
(0.984)\end{array}$ \\
\hline Size & $\begin{array}{c}1.265^{\star * *} \\
(0.100)\end{array}$ \\
\hline Growth & $\begin{array}{c}0.024^{\star * *} \\
(0.005)\end{array}$ \\
\hline Leverage & $\begin{array}{c}-2.410^{\star * *} \\
(0.216)\end{array}$ \\
\hline Constant & $\begin{array}{c}18.661^{* * *} \\
(0.381)\end{array}$ \\
\hline Observations & 12,366 \\
\hline Number of stock-code & 1,648 \\
\hline Breusch-pagan/Cook-Weisberg test & $182.02^{* * *}$ \\
\hline Hansen Test & 32.13 \\
\hline $\operatorname{AR}(1)$ & -7.25 \\
\hline $\operatorname{AR}(2)$ & -1.79 \\
\hline
\end{tabular}

Note: Return on equity is the dependent variable. Time dummies are incorporated in the model but not reported. Breusch-pagan/Cook-Weisberg test calculates the heteroskedasticity. Hansen test measures the validity of instrumental variables via overidentifying restrictions. Standard errors are in the parentheses. ${ }^{*} \mathrm{p}<0.1, \mathrm{p}^{\star *}<0.05,{ }^{* * *} \mathrm{p}<0.01$. 
However, the break-even point of the short-term borrowings and profit relation for the firms having reduced CCC moves to $0.45[-4.04 /(2 \times(-4.48))]$. It explains that firms carrying a reduced CCC period must have $45 \%$ short-term borrowings in the total external financing. However, this value is less than $52 \%$, a proportion of short-term borrowings in the full sample as reflected in Figure 1.

- Short-term borrowings $\square$ Long-term borrowings

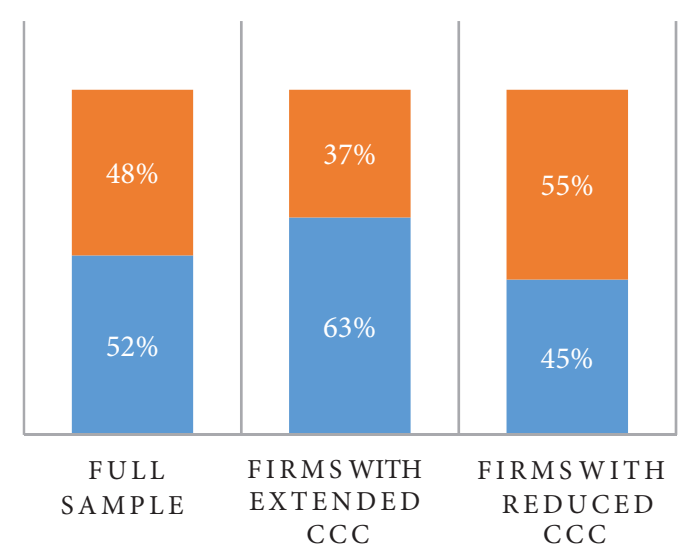

Figure 1. Short-term borrowings and Profitability under the influence of CCC

As CCC has been criticized by various researchers based on its calculation methodology, therefore, the current study divided the CCC into three components and evaluated the moderating role of each component in the short-term borrowings and profit relation.

\subsubsection{Short-term borrowings and Profitability under the moderating role of Account receivable days}

Results in Table 5 confirm the existence of an inverted U-shaped relation in short-term borrowings and profit for firms having extended account receivable days. This relationship is a combination of positive and negative trends, combined through a break-even point. The break-even point, in this case, is $0.64[-(3.69-1.5) /(2 \times(-3.73+2.03))]$ which explains that external financing must have a combination of $64 \%$ and $36 \%$ for short- and long-term borrowings.

However, the break-even point of the short-term borrowings and profit relation for the firms having reduced account receivable days moves to $0.50[-3.69 /(2 \times(-3.73))]$. It explains that firms having reduced account receivable days must have $50 \%$ short-term borrowings in the total external financing. However, this value is less than $52 \%$, the short-term borrowings in the full sample as reflected in Figure 2. 
Table 5. Short-term borrowings and Profitability for firms having reduced and extended account receivable days

\begin{tabular}{|l|c|}
\hline \multicolumn{1}{|c|}{ Variables } & Equation $(3)$ \\
\hline Short-term borrowings & $\begin{array}{c}3.690^{* * *} \\
(1.101)\end{array}$ \\
\hline Short-term borrowings2 & $\begin{array}{c}-3.739^{* * *} \\
(1.184)\end{array}$ \\
\hline Short-term borrowings ${ }^{\star} \mathrm{A} / \mathrm{R}$ days dummy & $\begin{array}{c}1.501^{* * *} \\
(0.520)\end{array}$ \\
\hline Short-term borrowings2 ${ }^{\star}$ A/R days dummy & $2.039^{* * *}$ \\
& $(0.705)$ \\
\hline Size & $\begin{array}{c}1.265^{* * *} \\
(0.889)\end{array}$ \\
\hline Growth & $\begin{array}{c}0.033^{* * *} \\
(0.005)\end{array}$ \\
\hline Leverage & $-2.199^{* * *}$ \\
& $(0.173)$ \\
\hline Constant & $-11.536^{* * *}$ \\
& $(0.872)$ \\
\hline Observations & 12,366 \\
\hline Number of stock-code & 1,648 \\
\hline Breusch-pagan/Cook-Weisberg test & $333.21^{* * *}$ \\
\hline Hansen Test & 43.78 \\
\hline AR(1) & -7.93 \\
\hline AR(2) & -1.89 \\
\hline
\end{tabular}

Note: Return on equity is the dependent variable. Time dummies are incorporated in the model but not reported. Breusch-pagan/Cook-Weisberg test calculates the heteroskedasticity. Hansen test measures the validity of instrumental variables via overidentifying restrictions. Standard errors are in the parentheses. ${ }^{*} \mathrm{p}<0.1, \mathrm{p}^{* *}<0.05,{ }^{* *} \mathrm{p}<0.01$.

Short-term borrowings $\square$ Long-term borrowings

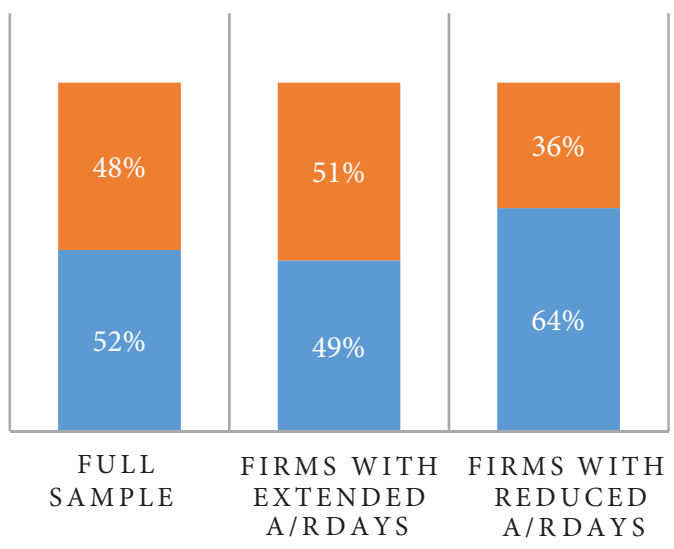

Figure 2. Short-term borrowings and Profitability under the influence of $A / R$ days 


\subsubsection{Short-term borrowings and Profitability under the moderating role of Account payable days}

Results in Table 6 confirm the existence of a U-shaped relation in short-term borrowings and profit for companies having reduced account payable days. This relationship is a combination of negative and positive trends, separated by a break-even point. The break-even point, in this case, is $0.42[-(-1.61 /(2 \times 1.93)]$ which explains that external financing must have a combination of $42 \%$ and $58 \%$ for short- and long-term borrowings.

Table 6. Short-term borrowings and Profitability for firms carrying reduced and extended account payable days

\begin{tabular}{|l|c|}
\hline \multicolumn{1}{|c|}{ Variables $^{\prime}$} & Equation $(4)$ \\
\hline Short-term borrowings & $-1.608^{* *}$ \\
& $(0.784)$ \\
\hline Short-term borrowings ${ }^{2}$ & $\begin{array}{c}1.938^{* *} \\
(0.868)\end{array}$ \\
\hline Short-term borrowings ${ }^{*}$ A/P Days dummy & $\begin{array}{c}1.055^{* * *} \\
(0.365)\end{array}$ \\
\hline Short-term borrowings ${ }^{2 *}$ A/P Days dummy & $-1.404^{* * *}$ \\
& $(0.507)$ \\
\hline Size & $\begin{array}{c}1.173^{* * *} \\
(0.087)\end{array}$ \\
\hline Growth & $\begin{array}{c}0.029^{* * *} \\
(0.005)\end{array}$ \\
\hline Leverage & $-1.686^{* * *}$ \\
& $(0.131)$ \\
\hline Constant & $-10.265^{* * *}$ \\
& $(0.869)$ \\
\hline Observations & 12,366 \\
\hline Number of stock-code & 1,648 \\
\hline Breusch-pagan/Cook-Weisberg test & $332.14^{* * *}$ \\
\hline Hansen Test & 84.35 \\
\hline AR(1) & -7.53 \\
\hline AR(2) & -2.29 \\
\hline
\end{tabular}

Note: Return on equity is the dependent variable. Time dummies are incorporated in the model but not reported. Breusch-pagan/Cook-Weisberg test calculates the heteroskedasticity. Hansen test measures the validity of instrumental variables via overidentifying restrictions. Standard errors are in the parentheses. ${ }^{*} \mathrm{p}<0.1, \mathrm{p}^{* *}<0.05,{ }^{* * *} \mathrm{p}<0.01$.

However, the break-even point of the short-term borrowings and profitability relationship for the firms having extended account payable days moves to $0.53[-(-1.61+1.05) /$ $(2 \times(1.93-1.40))]$. It explains that firms having extended account payable days must have $51 \%$ short-term borrowings in the total external financing. The graph in Figure 3 elaborates on the relationship of short-term borrowings and profitability under the moderating role of account payable days. 
- Short-term borrowings $\square$ Long-term borrowings

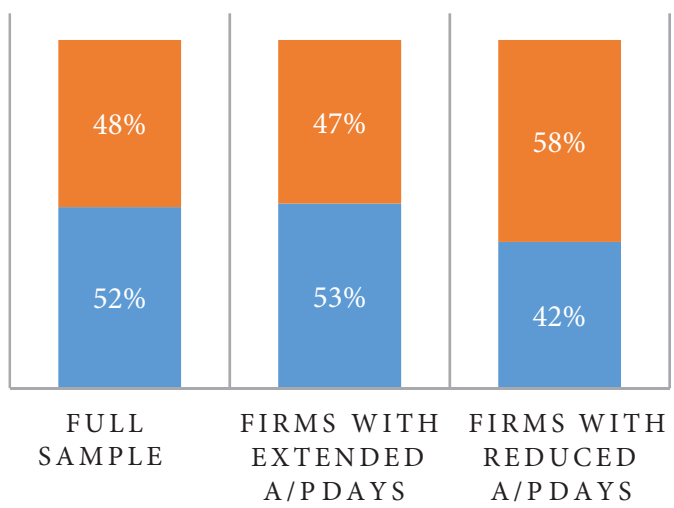

Figure 3. Short-term borrowings and Profitability under the influence of A/P days

\subsubsection{Short-term borrowings and Profitability under the moderating role of Inventory days}

Results in Table 7 confirm the existence of an inverted U-shaped relation in short-term borrowings and profit for firms having extended inventory days. This relationship is a

Table 7. Short-term borrowings and Profitability for firms carrying reduced and extended inventory days

\begin{tabular}{|c|c|}
\hline Variables & Equation (5) \\
\hline Short-term borrowings & $\begin{array}{c}3.178^{\star * *} \\
(1.161) \\
\end{array}$ \\
\hline Short-term borrowings ${ }^{2}$ & $\begin{array}{c}-3.125^{* * *} \\
(1.236)\end{array}$ \\
\hline Short-term borrowings ${ }^{\star} I n v$. Days dummy & $\begin{array}{c}-1.082^{* * *} \\
(0.523)\end{array}$ \\
\hline Short-term borrowings ${ }^{2 \star I n v . ~ D a y s ~ d u m m y ~}$ & $\begin{array}{c}1.436^{* * *} \\
(0.700)\end{array}$ \\
\hline Size & $\begin{array}{c}1.260^{\star * *} \\
(0.088)\end{array}$ \\
\hline Growth & $\begin{array}{c}0.032^{\star * *} \\
(0.005)\end{array}$ \\
\hline Leverage & $\begin{array}{c}-2.181^{\star * *} \\
(0.175)\end{array}$ \\
\hline Constant & $\begin{array}{c}-11.449^{* * *} \\
(0.868)\end{array}$ \\
\hline Observations & 12,366 \\
\hline Number of stock-code & 1,648 \\
\hline Breusch-pagan/Cook-Weisberg test & $326^{* * *}$ \\
\hline Hansen Test & 48.36 \\
\hline $\operatorname{AR}(1)$ & -7.75 \\
\hline $\mathrm{AR}(2)$ & -1.70 \\
\hline
\end{tabular}

Note: Return on equity is the dependent variable. Time dummies are incorporated in the model but not presented. Breusch-pagan/Cook-Weisberg test calculates the heteroskedasticity. Hansen test measures the validity of instrumental variables via overidentifying restrictions. Standard errors are in the parentheses. ${ }^{\star} \mathrm{p}<0.1, \mathrm{p}^{\star *}<0.05,{ }^{* * *} \mathrm{p}<0.01$. 
combination of positive and negative trends, combined through a break-even point. The break-even point, in this case, is $0.62[-(3.18-1.08) /(2 \times(-3.13+1.44))]$ which explains that external financing must have a combination of $62 \%$ and $38 \%$ for short- and long-term borrowings.

However, the break-even point of the short-term borrowings and profit relation, for the firms having reduced inventory days, moves to $0.51[-3.18 /(2 \times(-3.13))]$. It explains that firms having reduced inventory days must have $51 \%$ short-term borrowings in total external financing as reflected in Figure 4.

- Short-term borrowings $\square$ Long-term borrowings

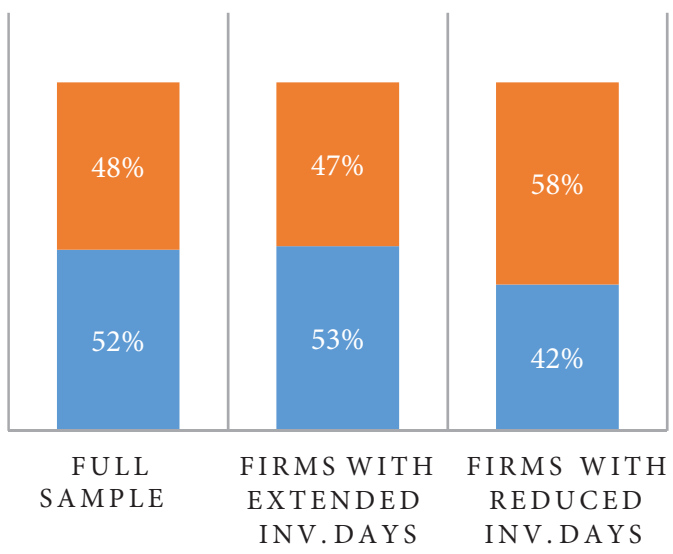

Figure 4. Short-term borrowings and Profitability under the influence of inventory days

\subsubsection{Robustness check}

We used the fixed-effect estimator for the robustness of the GMM results. Table 8 shows the detailed results of the fixed-effect model. All results are significant and robust to the GMM results except for the firms with less and extended account payable days, which carry the negative and positive coefficients of WCF and $\mathrm{WCF}^{2}$ resulting in a U-shaped WCF-Profitability relationship. The breakeven points of all firms except for the account payable days are also aligned with the GMM results which confirm that firms with extended CCC, particularly account receivable days and inventory days, use the less amount of short-term borrowings to finance the working capital. In a nutshell, the estimates of the fixed-effect method are consistent with the results produced by GMM, which implies that our findings are reliable.

\section{Discussion}

\subsection{WCF and firm performance}

The current study evaluates the WCF-Profitability relation for Chinese firms in the light of working capital management and capital structure theories. China has a unique banking system that is highly centralized and under the influence of the government; therefore, the 
Chines government persuades the banking sector to prefer the state-owned firms in granting the subsidized loans (Brandt \& Li, 2003). The results in a Table 4 disclose that when the proportion of WCF changes, the profitability of the firm also fluctuates. These results are consistent with the theory of capital structure proposed by Modigliani and Miller (1958), which states that financing options in the real-world influence the firm performance. The results are also consistent with previous studies (Baños-Caballero et al., 2016; Mahmood et al., 2019; Panda \& Nanda, 2018), which disclose the inverted U-shaped relation in WCF and firm performance. Chinese banks are under the influence of the central government and there-

Table 8. Short-term borrowings and Profitability relation estimation using the fixed-effect model for firms under the moderating role of CCC and its components

\begin{tabular}{|c|c|c|c|c|c|}
\hline Variables & $\begin{array}{l}\text { Equation } \\
\text { (1) }\end{array}$ & $\begin{array}{l}\text { Equation } \\
\text { (2) }\end{array}$ & $\begin{array}{l}\text { Equation } \\
\text { (3) }\end{array}$ & $\begin{array}{l}\text { Equation } \\
\text { (4) }\end{array}$ & $\begin{array}{c}\text { Equation } \\
\text { (5) }\end{array}$ \\
\hline Short-term borrowings & $\begin{array}{c}0.500^{\star * *} \\
(0.068)\end{array}$ & $\begin{array}{c}0.467^{* * *} \\
(0.078)\end{array}$ & $\begin{array}{c}0.207^{* * *} \\
(0.079)\end{array}$ & $\begin{array}{c}-0.450^{\star * *} \\
(0.077)\end{array}$ & $\begin{array}{c}0.483^{* * *} \\
(0.079)\end{array}$ \\
\hline Short-term borrowings ${ }^{2}$ & $\begin{array}{l}-0.310^{* * *} \\
(0.071)\end{array}$ & $\begin{array}{l}-0.284^{* * *} \\
(0.088)\end{array}$ & $\begin{array}{l}-0.163^{*} \\
(0.088)\end{array}$ & $\begin{array}{l}-0.296^{* * *} \\
(0.089)\end{array}$ & $\begin{array}{l}-0.294^{* * *} \\
(0.089)\end{array}$ \\
\hline $\begin{array}{l}\text { Short-term borrowings }{ }^{\star} \text { CCC } \\
\text { dummy }\end{array}$ & & $\begin{array}{l}0.065^{*} \\
(0.072)\end{array}$ & & & \\
\hline $\begin{array}{l}\text { Short-term borrowings }{ }^{2 *} \mathrm{CCC} \\
\text { dummy }\end{array}$ & & $\begin{array}{l}0.055^{*} \\
(0.100)\end{array}$ & & & \\
\hline $\begin{array}{l}\text { Short-term borrowings }{ }^{\star} \mathrm{A} / \\
\text { CReceivable Days dummy }\end{array}$ & & & $\begin{array}{c}-0.107^{* *} \\
(0.071)\end{array}$ & & \\
\hline $\begin{array}{l}\text { Short-term borrowings }{ }^{2 *} \mathrm{~A} / \mathrm{C} \\
\text { Receivable Days dummy }\end{array}$ & & & $\begin{array}{l}0.084^{\star} \\
(0.099)\end{array}$ & & \\
\hline $\begin{array}{l}\text { Short-term borrowings }{ }^{\star} \mathrm{A} / \mathrm{C} \\
\text { Payable days dummy }\end{array}$ & & & & $\begin{array}{l}-0.119^{*} \\
(0.068)\end{array}$ & \\
\hline $\begin{array}{l}\text { Short-term borrowings }{ }^{2 *} \mathrm{~A} / \mathrm{C} \\
\text { Payable Days dummy }\end{array}$ & & & & $\begin{array}{l}0.055^{\star} \\
(0.097)\end{array}$ & \\
\hline $\begin{array}{l}\text { Short-term borrowings^Inv. } \\
\text { Days dummy }\end{array}$ & & & & & $\begin{array}{c}-0.009^{* *} \\
(0.072)\end{array}$ \\
\hline $\begin{array}{l}\text { Short-term borrowings }{ }^{2 *} \text { Inv. } \\
\text { Days dummy }\end{array}$ & & & & & $\begin{array}{l}-0.016^{* *} \\
(0.0100)\end{array}$ \\
\hline Size & $\begin{array}{c}-0.029^{* * *} \\
(0.015) \\
\end{array}$ & $\begin{array}{l}-0.030^{\star} \\
(0.015) \\
\end{array}$ & $\begin{array}{c}0.014 \\
(0.014) \\
\end{array}$ & $\begin{array}{l}0.026^{*} \\
(0.015) \\
\end{array}$ & $\begin{array}{l}-0.046^{\star} \\
(0.022) \\
\end{array}$ \\
\hline Growth & $\begin{array}{c}0.025^{* * *} \\
(0.001)\end{array}$ & $\begin{array}{c}0.024^{* * *} \\
(0.001)\end{array}$ & $\begin{array}{c}0.024^{* * *} \\
(0.001)\end{array}$ & $\begin{array}{c}0.024^{* * *} \\
(0.001)\end{array}$ & $\begin{array}{c}0.024^{* * *} \\
(0.001)\end{array}$ \\
\hline Leverage & $\begin{array}{c}-0.151^{\star * *} \\
(0.036)\end{array}$ & $\begin{array}{c}-0.156^{* * *} \\
(0.041)\end{array}$ & $\begin{array}{c}-0.644^{* * *} \\
(0.043)\end{array}$ & $\begin{array}{c}-0.147^{* * *} \\
(0.040)\end{array}$ & $\begin{array}{l}-0.154^{* * *} \\
(0.040)\end{array}$ \\
\hline Constant & $\begin{array}{l}0.695^{\star *} \\
(0.140) \\
\end{array}$ & $\begin{array}{c}0.710^{* * *} \\
(0.141) \\
\end{array}$ & $\begin{array}{c}-0.7456^{* * *} \\
(0.137)\end{array}$ & $\begin{array}{c}-0.670^{\star \star *} \\
(0.141)\end{array}$ & $\begin{array}{c}-2.448^{* * *} \\
(0.162)\end{array}$ \\
\hline Hausman Test & $375.02^{* * *}$ & & & & \\
\hline $\mathrm{R}^{2}$ & 0.187 & 0.181 & 0.182 & 0.180 & 0.182 \\
\hline
\end{tabular}

Note: Return on equity is the dependent variable. Hausman test measures the suitability of the fixed-effect model on the given data $\mathrm{R}^{2}$ measures the accuracy of the model. Standard errors are in the parentheses. ${ }^{*} \mathrm{p}<0.1, \mathrm{p}^{* *}<0.05,{ }^{* * *} \mathrm{p}<0.01$. 
fore favor the government-owned firms in granting the loans. This polarized behavior of the government-controlled banking system of China also plays no role in the WCF-Profitability relation because the results are in line with similar studies conducted in India and Europe.

The initial positive relation between short-term borrowings and profit is due to the advantages linked with short-term borrowings, including favorable credit terms, lower interest, avoiding agency cost, and expansion of positive prospects among all the stakeholders. However, as short-term borrowings increase, this relationship weakens due to the disadvantages related to short-term borrowings. On a further rise in short-term borrowings, the positive relationship eventually becomes zero at a particular stage, called break-even point. After that, negative WCF-Profitability relation starts prevailing due to the disadvantages linked with short-term borrowings. These disadvantages mainly include refinancing uncertainties and high-interest rates. So, the break-even point is the position where profit is maximum, and at this point, the proportion of short-term borrowings in total external financing best suits the company.

\subsection{Role of CCC in WCF and firm performance relationship}

According to the theory of working capital management, firms having extended CCC prefer liquidity over profitability and therefore follow a conservative strategy in CCC. As per results, the same theory also prevails in the financing of working capital for such firms. Therefore, these firms have a dominant portion of long-term financing in working capital, which is according to the conservative approach of working capital management theory. This is the reason that short-term borrowings, for firms having extended CCC, moved to 63\% compared to the $52 \%$ i-e the short-term borrowings in the full sample. These results validate Hypothesis $2 \mathrm{a}$ which states that firms that carry extended CCC maintain a small proportion of short-term borrowings in external financing, compared to the full sample. The firms with reduced CCC carry short-term borrowingsas $45 \%$, which is less than $52 \%$, a proportion of short-term borrowings in the full sample. These results support hypothesis $2 \mathrm{~b}$.

\subsection{Role of account receivable days in WCF and firm performance relationship}

According to the theory of working capital management, firms having extended account receivable days prefer liquidity over profitability and therefore follow a conservative strategy. As per results, the same theory also prevails in the financing of working capital for such firms. Therefore, these firms have a dominant portion of long-term financing in working capital, which is according to the conservative approach of working capital management theory. This is the reason that short-term borrowings for such firms move to $64 \%$ compared to the $52 \%$ i-e the short-term borrowings in the full sample. These results validate Hypothesis $3 \mathrm{a}$ which states that firms that carry extended account receivable days, maintain a large proportion of short-term borrowings in external financing, compared to the full sample.

The firms with reduced account receivable days carry the breakeven point of 0.49 , which is less than $52 \%$, a proportion of short-term borrowings in the full sample. It explains that firms having reduced account receivable days maintain $49 \%$ short-term borrowings in the total external financing. These results support Hypothesis $3 \mathrm{~b}$. 


\subsection{Role of Account Payable Days in WCF and firm performance relationship}

According to the theory of working capital management, firms having extended account payable days prefer profitability over liquidity by following an aggressive strategy in account payables. We expect the same strategy of working capital management theory in financing the working capital of such firms. However, results reveal that these firms have a dominant portion of long-term financing in working capital, which is according to the conservative approach of working capital management theory. This is the reason that short-term borrowings for such firms move to $53 \%$ compared to the $52 \%$ i-e the short-term borrowings in the full sample. These results validate hypothesis $4 \mathrm{a}$ which states that firms that carry extended account payable days, maintain a small proportion of short-term borrowings in external financing, compared to the full sample.

The firms with reduced account payable days carry the breakeven point of 0.42 , which is also less than $52 \%$, a proportion of short-term borrowings in the full sample. It explains that firms having reduced account payable days must have $42 \%$ short-term borrowings in the total external financing. These results state that the theory of working capital management also prevails in such firms, which follows a conservative strategy in financing the working capital.

\subsection{Role of inventory days in WCF and firm performance relationship}

The breakeven point for a firm with extended inventory days is 0.62 , which is more than 0.52 , the break-even point of the entire sample. It means, these results validate our Hypothesis $5 \mathrm{a}$, which says that firms that maintain a high level of inventory need a large proportion of shortterm borrowings in external financing compared to the full sample.

According to the theory of working capital management, firms having extended inventory days prefer liquidity over profitability and therefore follow a conservative strategy. As per results, the same theory also prevails in the financing of working capital for such firms. Therefore, these firms have a dominant portion of long-term financing in working capital, which is according to the conservative approach of working capital management theory. This is the reason that short-term borrowings for such firms move to $62 \%$ compared to the $52 \%$ i-e the short-term borrowings in the full sample. These results validate Hypothesis $5 \mathrm{a}$ which states that firms that carry extended inventory days, maintain a large proportion of shortterm borrowings in external financing, compared to the full sample.

The firms with reduced inventory days carry the breakeven point of 0.51 , which is less than 0.52 , a proportion of short-term borrowings in the full sample. It explains that firms having reduced inventory days must have 50\% short-term borrowings in total external financing. These results support Hypothesis $5 \mathrm{~b}$.

\section{Conclusions}

The current study examined the short-term borrowings and profitability relation in Chinese companies under the influence of CCC and its components during the period 2000 to 2017. This study used the two-step system GMM estimator, an advanced panel data technique that 
accounts for potential endogeneity and heteroskedasticity problems with greater strength. We checked the robustness of results using the fixed-effect estimator.

The results confirm the existence of an inverted U-shaped relation in short-term borrowings and profit in the context of Chinese firms. The findings also validate the moderating role of CCC and its components in this relationship. More specifically, the results elaborate that firms with extended CCC period require less amount of short-term borrowings compared to the full sample. The current study also conducted the disaggregate analysis for three components of extended CCC i-e extended account receivable days, reduced account payable days, and extended inventory days. The results show similar outcomes for three components of extended CCC, thus, confirming the robustness of our results.

This study provides valuable information belonging to the policymakers and managers for achieving the optimum relationship in short-term borrowings and profit. Particularly, the firms following a conservative strategy in CCC and its components should use the large proportion of short-term borrowings in total external financing. Similarly, firms following an aggressive strategy in CCC and its components should use a large proportion of short-term borrowings in the total external financing to maximize the profit.

This study controls some firm-specific characteristics and also not incorporate macroeconomic elements like GDP growth, inflation, and monetary policy. Future studies may consider these factors to evaluate their role in short-term borrowings and profit relation. The current study also extracted the data from the manufacturing sector only. Revising the same study in the non-manufacturing firms might reveal interesting differences. Furthermore, our study is based on unbalanced data. So, the current results can be confirmed using the balanced data, which better suits the panel data analytical techniques.

\section{Funding}

This work was supported by the National Natural Science Foundation of China under Grant No. 71672046.

\section{References}

Afrifa, G. A., Padachi, K., Nasir, M. A., \& Morgan, J. (2016). Working Capital level influence on SME profitability. Journal of Small Business and Enterprise Development, 23(1), 44-63.

https://doi.org/10.1108/MRR-09-2015-0216

Altaf, N. (2018). Do financial development and law enforceability effect the relationship between net working capital and firm value? Empirical evidence from Asia. American Journal of Business, 33(3), 120-132. https://doi.org/10.1108/AJB-11-2017-0034

Altaf, N., \& Ahmad, F. (2019). Working capital financing, firm performance and financial constraints: Empirical evidence from India. International Journal of Managerial Finance, 15(4), 464-477. https://doi.org/10.1108/IJMF-02-2018-0036

Baños-Caballero, S., García-Teruel, P. J., \& Martínez-Solano, P. (2010). Working capital management in SMEs. Accounting and Finance, 50(3), 511-527. https://doi.org/10.1111/j.1467-629X.2009.00331.x

Baños-Caballero, S., García-Teruel, P. J., \& Martínez-Solano, P. (2012). How does working capital management affect the profitability of Spanish SMEs? Small Business Economics, 39(2), 517-529.

https://doi.org/10.1007/s11187-011-9317-8 
Baños-Caballero, S., García-Teruel, P. J., \& Martínez-Solano, P. (2013). The speed of adjustment in working capital requirement. European Journal of Finance, 19(10), 978-992.

https://doi.org/10.1080/1351847X.2012.691889

Baños-Caballero, S., García-Teruel, P. J., \& Martínez-Solano, P. (2016). Financing of working capital requirement, financial flexibility and SME performance. Journal of Business Economics and Management, 17(6), 1189-1204. https://doi.org/10.3846/16111699.2015.1081272

Baños-Caballero, S., García-Teruel, P. J., \& Martínez-Solano, P. (2019). Net operating working capital and firm value: A cross-country analysis. BRQ Business Research Quarterly (In press). https://doi.org/10.1016/j.brq.2019.03.003

Baum, C. F., Schaffer, M. E., \& Stillman, S. (2003). Instrumental Variables and GMM: Estimation and Testing. The Stata Journal: Promoting Communications on Statistics and Stata, 3(1), 1-31. https://doi.org/10.1177/1536867X0300300101

Blundell, R., \& Bond, S. (1998). Initial conditions and moment restrictions in dynamic panel data models. Journal of Econometrics, 87(1), 115-143. https://doi.org/10.1016/S0304-4076(98)00009-8

Brandt, L., \& Li, H. (2003). Bank discrimination in transition economies: Ideology, information, or incentives? Journal of Comparative Economics, 31(3), 387-413. https://doi.org/10.1016/S0147-5967(03)00080-5

Chauhan, G. S., \& Banerjee, P. (2018). Financial constraints and optimal working capital - evidence from an emerging market. International Journal of Managerial Finance, 14(1), 37-53. https://doi.org/10.1108/IJMF-07-2016-0131

Dalci, I., \& Ozyapici, H. (2018). Working capital management policy in health care: The effect of leverage. Health Policy, 122(11), 1266-1272. https://doi.org/10.1016/j.healthpol.2018.09.012

Eldomiaty, T., Anwar, M., \& Ayman, A. (2018). How can firms monitor the move toward optimal working capital? Journal of Economic and Administrative Sciences, 34(3), 217-236.

https://doi.org/10.1108/JEAS-06-2017-0056

Gao, J., \& Wang, J. (2017). Is working capital information useful for financial analysts? Evidence from China. Emerging Markets Finance and Trade, 53(5), 1135-1151.

https://doi.org/10.1080/1540496X.2016.1278166

Gill, A., Mand, H. S., Obradovich, J. D., \& Mathur, N. (2019). The impact of working capital management on the decision of Indian production firms about the amount of dividends. International Journal of Business and Globalisation, 22(3), 372-388. https://doi.org/10.1504/IJBG.2019.099300

Goel, U., \& Sharma, A. K. (2015). Analysing efficiency change in working capital management using Malmquist Productivity Index. Journal of Information and Optimization Sciences, 36(6), 595-616. https://doi.org/10.1080/02522667.2015.1047586

Li, F. (2016). Endogeneity in CEO power: A survey and experiment. Investment Analysts Journal, 45(3), 149-162. https://doi.org/10.1080/10293523.2016.1151985

Lyngstadaas, H., \& Berg, T. (2016). Working capital management: Evidence from Norway. International Journal of Managerial Finance, 12(3), 295-313. https://doi.org/10.1108/IJMF-01-2016-0012

Kieschnick, R., Laplante, M., \& Moussawi, R. (2013). Working capital management and shareholders' wealth. Review of Finance, 17(5), 1827-1852. https://doi.org/10.1093/rof/rfs043

Laghari, F., \& Chengang, Y. (2019). Investment in working capital and financial constraints: Empirical evidence on corporate performance. International Journal of Managerial Finance, 15(2), 164-190. https://doi.org/10.1108/IJMF-10-2017-0236

Mahmood, F., Dongping, H., Abbas, A., Ibrar, M., \& Ali, N. (2018). Effects of working capital management on firms' performance: Empirical study in Pakistan. In Proceedings of the $32^{\text {nd }}$ International Business Information Management Association Conference, IBIMA 2018 - Vision 2020: Sustainable Economic Development and Application of Innovation Management from Regional Expansion to Global Growth (pp. 1098-1107). https://doi.org/10.6007/IJARBSS/v4-i6/931 
Mahmood, F., Han, D., Ali, N., Mubeen, R., \& Shahzad, U. (2019). Moderating effects of firm size and leverage on the working capital finance-profitability relationship: Evidence from China. Sustainability, 11(7), 19-22. https://doi.org/10.3390/su11072029

Masri, H., \& Abdulla, Y. (2018). A multiple objective stochastic programming model for working capital management. Technological Forecasting and Social Change, 131(January), 141-146. https://doi.org/10.1016/j.techfore.2017.05.006

Modigliani, F., \& Miller, M. H. (1958). The cost of capital, corporation finance and theory of investment. The American Economic Review, 48(3), 261-267.

Moussa, A. A. (2018). The impact of working capital management on firms' performance and value: Evidence from Egypt. Journal of Asset Management, 19(4), 259-273. https://doi.org/10.1057/s41260-018-0081-Z

Panda, A. K. K., \& Nanda, S. (2018). Working capital financing and corporate profitability of Indian manufacturing firms. Management Decision, 56(2), 441-457. https://doi.org/10.1108/MD-07-2017-0698

Shahzad, U., Fukai, L., Mahmood, F., Jing, L., \& Ahmad, Z. (2020). Reliable and Advanced predictors for corporate financial choices in Pakistan. The Journal of Asian Finance, Economics and Business, 7(7), 73-84. https://doi.org/10.13106/jafeb.2020.vol7.no7.073

Smith, K. (1980). Profitability versus liquidity tradeoffs in working capital management. In Readings on the management of working capital (pp. 549-562).

Tahir, M., \& Anuar, M. B. A. (2016). The determinants of working capital management and firms performance of textile sector in pakistan. Quality and Quantity, 50(2), 605-618. https://doi.org/10.1007/s11135-015-0166-4

Tsuruta, D. (2019). Working capital management during the global financial crisis: Evidence from Japan. Japan and the World Economy, 49(January), 206-219. https://doi.org/10.1016/j.japwor.2019.01.002 